\begin{tabular}{|c|c|c|c|c|c|c|}
\hline \multirow{4}{*}{ Impact Factor: } & ISRA (India) & $=3.117$ & SIS (USA) & $=0.912$ & ICV (Poland) & $=6.630$ \\
\hline & ISI (Dubai, UAE & $=0.829$ & РИНЦ (Russia & $=\mathbf{0 . 1 5 6}$ & PIF (India) & $=1.940$ \\
\hline & GIF (Australia) & $=0.564$ & ESJI (KZ) & $=8.716$ & IBI (India) & $=4.260$ \\
\hline & JIF & $=1.500$ & SJIF (Morocco & $=\mathbf{5 . 6 6 7}$ & OAJI (USA) & $=0.350$ \\
\hline
\end{tabular}

\section{SOI: 1.1/TAS DOI: 10.15863/TAS International Scientific Journal Theoretical \& Applied Science}

\author{
p-ISSN: 2308-4944 (print) e-ISSN: 2409-0085 (online) \\ Year: $2019 \quad$ Issue: $04 \quad$ Volume: 72
}

Published: $24.04 .2019 \quad$ http://T-Science.org
QR - Issue

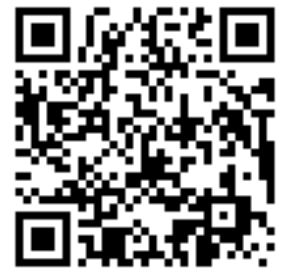

Jamshid Ergashevich Rustamov

Samarkand Institute of Economics and Service

\title{
CURRENT STATE OF USE OF INFORMATION AND DISTANCE LEARNING TECHNOLOGIES IN THE DEVELOPMENT OF SKILLS IN THE ELECTRONIC INFORMATION ENVIRONMENT OF TODAY'S ECONOMISTS
}

\begin{abstract}
The article addresses the issues the content of advanced training of economists in the electronic information environment and improvement of quality requirements based on modern approaches, periodically during professional activities and issues of improving the methodology of lifelong learning. In addition, forms of distance learning, distance learning methods and the importance of these methods.

Key words: forms of distance learning, lectures, consultations, laboratory work, exhibition experiments, observation, independent work, webinars, distance learning methods, abstracts, information gathering method, reproductive method.

Language: English

Citation: Rustamov, J. E. (2019). Current state of use of information and distance learning technologies in the development of skills in the electronic information environment of today's economists. ISJ Theoretical \& Applied Science, 04 (72), 342-346.
\end{abstract}

Soi: http://s-o-i.org/1.1/TAS-04-72-42 Doi: crossef https://dx.doi.org/10.15863/TAS.2019.04.72.42

\section{Introduction}

Development of modern informationcommunication and distance learning technologies and interactive methods of teaching in the educational system, as well as in the developed countries of the world, the provision of modern educational and laboratory equipment, curricula, teaching and methodological literature to the international standards, in particular, with the use of advanced pedagogical and information-communication technologies.

It is crucial to ensure that communication is in conformity with the educational practice and the development of mechanisms for the timely introduction of advanced pedagogical and information technologies in the process of developing the skills of economists in the electronic information environment.

The First President of the Republic of Uzbekistan I.Karimov emphasized the importance of modern information and communication technologies. it is not difficult to be able to see and understand the example of his experience."

During the years of independence, educational institutions were equipped with computers, Internet access, ZiyoNet network and electronic communication. As a result of these efforts, the modern information and communication technologies (ICT) tools have been introduced to the educational process, as well as new methods of teaching the modern requirements in the field of modern information technologies (Carter, Gartner, \& Reynolds, 1996; Kalpakjian \& Schmid, 2014; Welch \& Yang, 2011).

\section{Research background}

The Resolution of the Cabinet of Ministers of the Republic of Uzbekistan "On further improvement of the system of retraining and improvement of professional skill of the pedagogical staff" from February 16, 2006 №2 "is based on the interactive methods of teaching, modern pedagogical approach aimed at stimulating the critical and creative thinking of pedagogues using the global Internet network and introduction of information technologies "and" Scientific and methodological basis of retraining and professional development of pedagogical staff " and "development and introduction of distance learning in the system of retraining and advanced training of personnel". 


\begin{tabular}{|c|c|c|c|c|c|c|}
\hline \multirow{4}{*}{ Impact Factor: } & ISRA (India) & $=3.117$ & SIS (USA) & $=0.912$ & ICV (Poland) & $=6.630$ \\
\hline & ISI (Dubai, UAE & $=0.829$ & РИНЦ (Russia & $=0.156$ & PIF (India) & $=1.940$ \\
\hline & GIF (Australia) & $=0.564$ & ESJI (KZ) & $=8.716$ & IBI (India) & $=4.260$ \\
\hline & JIF & $=1.500$ & SJIF (Morocco & $=\mathbf{5 . 6 6 7}$ & OAJI (USA) & $=0.350$ \\
\hline
\end{tabular}

In order to ensure the implementation of these tasks, it is planned to develop the scientific and methodological foundations of the economics in the electronic information environment and to use interactive methods of teaching directed to the development of critical and creative thinking of teachers, as well as modern pedagogical, information and distance learning technologies, the development of educational and methodological support for the development of education is crucial sb leads.

\section{Main part}

The Strategic Action Strategy of the President of the Republic of Uzbekistan for five promising areas of development of the Republic of Uzbekistan for 20172021 set out the task of "Deeply studying the quality of education in the educational institution, such as economics, information technology and deep study of the most demanding subjects."

The adoption of the Resolution of the President of the Republic of Uzbekistan from September 14, 2017 "On establishing a specialized school for the deepening of knowledge in the field of information and communication technologies named after Muhammad al-Khwarizmi", accelerated development of modern information and communication technologies in this area has made the training of qualified personnel an extremely important task. The introduction of communication technologies in foreign countries in all sectors of the economy has a significant impact on the socio-economic and economic development of the country (Alsos \& Clausen, 2014; BOBUR et al., 2015; Eastman \& Burgess, 2009; Mukhtarov, Fox, Mukhamedova, \& Wegerich, 2015).

Positive growth of the economy leads to the introduction of new investments in the sphere of information and communication technologies. The most important investment is the training of personnel and their devotion to youth.

The establishment of a specialized school for deeper and deeper education in the field of information and communication technologies named after Muhammad al-Khwarizmi, our great ancestor, is the first step towards this goal.

In recent years, major reforms have been carried out in the Republic of Uzbekistan to introduce modern information and communication technologies into all areas of society, including public administration, society, education, and public services.

Establishment of this school will help to train the cadres who will be able to respond to this call of the age, prepare specialists who meet the requirements of the field and meet the requirements of the age.

Implementation of these tasks includes laboratory work, demonstration experiences, solving issues in the process of integrating natural and virtual forms of education in the process of education, development of the requirements for education based on modern approaches, the development of modern information and communication technologies in all areas of society, government, society, education, and healthcare, as well as the study of national and global achievements in the provision of public services. up to date.

From the world experience analysis, it can be seen that the following economics need to address the following problems in the organization and implementation of distance learning in the electronic information environment: $[3,5,6]$.

1. Distance learning is a specific form of teaching which is distinguished by the use of a set of specific teaching methods, methods, tools and forms that are primarily used by ICT tools. In order to receive distance learning, ICT should be able to apply the required level of education and be able to access electronic textbooks, e-learning manuals, virtual laboratory works and the internet.

2 . In contrast to conventional forms of education, it requires training of specialists in distance learning institutions. The distance learning system technician is required not only to become an ICT expert and to be a technology expert in distance learning courses.

3 . In the introduction of distance learning at the educational institution it is necessary to develop the curricula and materials of distance learning and the technology of teaching. Creating a remote course is complicated and time consuming. Methodist, teacher and programmers should work together in organizing it. This year's economists need to use advanced training courses, curricula, advanced forms, methods, tools and technologies for teaching and learning on the basis of national requirements for the content and quality of foreign experience and cadres.

4. The use of distance learning in the system of professional training of economic personnel is of the utmost importance, in addition to the personal, professional knowledge of the future staff, they should be prepared to use this form of education in their practice.

In the development of the content of distance learning, it must be based on a competent approach aimed at practicing the knowledge gained in practice. This is because the students are trained on the basis of State educational standards based on a competent approach, which required

5. The specifications of the subject matter in the field of distance learning should not only define the content and structure of the teaching, but also be reflected in the chosen model of instruction. It is 


\begin{tabular}{|c|c|c|c|c|c|c|}
\hline \multirow{4}{*}{ Impact Factor: } & ISRA (India) & $=3.117$ & SIS (USA) & $=0.912$ & ICV (Poland) & $=6.630$ \\
\hline & ISI (Dubai, UAE & $=0.829$ & РИНЦ (Russia & $=0.156$ & PIF (India) & $=1.940$ \\
\hline & GIF (Australia) & $=0.564$ & ESJI (KZ) & $=8.716$ & IBI (India) & $=4.260$ \\
\hline & JIF & $=1.500$ & SJIF (Morocco & $=\mathbf{5 . 6 6 7}$ & OAJI (USA) & $=0.350$ \\
\hline
\end{tabular}

necessary to develop a clear model of the educational process. This model should be aimed at ensuring the peculiarities of the teaching, the requirements for the content and quality of education.

6. In the distance learning, there are additional normative documents in the pedagogical institutions that include teachers' loads (learning curricula, curriculum oversight, counseling, etc.). Availability of these documents will have a positive effect on the effectiveness of distance learning.

\section{Institutional basis of the research}

It is necessary to develop normative documents regulating distance learning, government requirements, basic curriculum, and curriculum.

In our opinion, the above problems encountered in the implementation of distance learning can be effective only when a positive solution is found.

In particular, many are highly appreciating the teaching of modern humanitarian, lifestyle experiences, collaborative learning, individualization of the educational process, and self-actualization [4].

The general requirements for the organization of training on the above principles include the following: Compilation of methodological recommendations (explanation, knowledge, design, reflection, etc.), individualization and intellectualization of methods and rules of study, humanization of knowledge, creative adoption of the educational material, communicative and informatics of didactic means, high motivation for teaching a high level of awareness of the audience.

Nowadays, education is a form of distance education that fully meets these requirements.

\section{Forms of distance learning.}

The traditional form of education, classroom, has the most prominent forms of teaching, such as lectures, seminars, laboratory workshops, practical exercises, problem solving, demonstration experiments, supervision, qualification, test scrutiny, counseling and independent work. All of them have a place in the distance learning system.

We will consider some of the features of using the above-mentioned training forms.

The lecture is a basic form of training for the theoretical preparation of learners. Requirements such as the generality of the subject matter of the distance education, such as the scientific, publicity, the form and the content, the relationship with other types of training, remain.

There are different approaches to reporting in the distance learning system. The answer is "Electronic Speech". The Electronic Speech also includes lecture texts, including supplementary materials - scientific articles, manuals, laboratory works, demonstrative experiments, methodological recommendations and other learning materials. Electronic Speech provides the audience with the opportunity to think, analyze, analyze, and repeatedly repeat the text.

Consultations - this can be one of the individual and group interventions, one of the exercises in the way of working with the audience and assisting them in the study of learning materials. During the consultations, attitudes, attitudes, thinking, thinking skills, from the personal characteristics of the listener, are influenced by intellectual, moral qualities, especially the mind and psychological traits.

Consultations with tutors and listeners on complex or actual issues of teaching methodology in distance learning are mainly carried out by phone, email, web site.

Laboratory Work, Demonstration Experiments, Solving Problems. This type of workshop is of great importance in the process of teaching.

The practical application of the knowledge gained in practice can only be thoroughly mastered on the basis of theoretical knowledge, experiments, laboratory work and solving issues. Therefore, while providing theoretical knowledge, laboratory work, demonstration experiences, organization and dissemination of these issues are essential components of the learning process to consolidate, deepen, extend and implement these knowledges.

There were some problems with practical training in the research process. In particular, all educational and laboratory equipment provided at the distance learning centers is designed to organize and conduct classes in classroom form. These sessions need to be organized and organized in virtual form. This indicates that we need to conduct separate research.

\section{Controls.}

The control over the distance learning process is related to examining the results of theoretical and practical learning of the study material.

Based on the experiences in this area, many experts choose a test for knowledge assessment and emphasize the possibility that a large number of trainees have the opportunity to demonstrate their knowledge and skills in the same way. Some experts also agree with the test questions, exercises, and assignments.

In our opinion, the evaluation can be a prerequisite for the test, but it can not be the only system for evaluating economic competence and professionalism. Different evaluation forms were used in the distance learning course during the research. Such forms of evaluation include diagnostic questions, exercises and assignments for selfexamination.

\section{Independent work.}

This is a well-known form in the traditional education system. However, it is essential for distance learning that the independent work of the audience 


\begin{tabular}{|c|c|c|c|c|c|c|}
\hline \multirow{4}{*}{ Impact Factor: } & ISRA (India) & $=3.117$ & SIS (USA) & $=0.912$ & ICV (Poland) & $=6.630$ \\
\hline & ISI (Dubai, UAE & $=0.829$ & РИНЦ (Russia & $=\mathbf{0 . 1 5 6}$ & PIF (India) & $=1.940$ \\
\hline & GIF (Australia) & $=0.564$ & ESJI (KZ) & $=8.716$ & IBI (India) & $=4.260$ \\
\hline & JIF & $=1.500$ & SJIF (Morocco & $=5.667$ & OAJI (USA) & $=0.350$ \\
\hline
\end{tabular}

may be individual, dual or grouped. It is known from experience that the process of self-organization of the group members in the process of independent work, showing its positive aspects.

To be effective in the distance learning courses, it is necessary to have independent learning skills, independent study materials and planning methods.

Webinar is the way to interact with the audience through the Internet using special software [2]. The term "webinar" is derived from the English word "webinar" and represents a seminar through a network [2, $3 \mathrm{~b}]$.

At the distance learning course, the technicians will be able to present a variety of notes and drawings on the subject of the seminar on a virtual web page, including presentation of text documents, various multimedia tools, virtual labs during the webinar, as well as working in traditional electronic format will be created (Kalpakjian \& Schmid, 2014; Sobirov, 2018).

\section{Methods of Distance Education.}

The industry specialists classify the techniques used in the distance learning process and incorporate all techniques into the following 4 groups.

1. Methods for ensuring the independent learning of learning resources, taking into account the minimal attitudes of tutors and educators in the learning process.

Based on these techniques, the use of various educational resources for modules and themes, based on the curriculum for distance learning. This includes electronic textbooks, e-learning aids, virtual labs, virtual stands, software solutions, and other materials available on the Web.

2. Individual methods of teaching and studying (single-method of learning), from one tutor's ability to interact with a tutor or one other trainee.

These methods are based on interactive collaboration programs on topics such as telephone, email, curriculum, and distance education.

3. Methods based on teacher training material that do not play an active role in communication (one training a person).

These methods are unique to the traditional education system and are developing on the basis of modern information technology. For example, lectures in the form of classroom lessons will be replaced by lectures in video and web conferencing, webinar formats for distance learning.

4. Methods for communicating effectively between all participants in the learning process ("majority-majority" education).

The importance of these methods is that their utilization significantly increases due to the intensive development of ICT. These methods, combined with subgrouping, focus on collaborative learning and are of great interest to distance learning. It is also known from the experiences that these methods are effective in addressing individual learning problems.

\section{Conclusion}

Understanding of the individual skills of future staff and achievement of concrete results in the teaching methodology, laboratory work, demonstrative experiments, the organization and carrying out of the problem solving in distance learning opportunities will allow to understand the ways of solving various problems during their professional activity.

Despite the diversity of distance learning experts, almost all authors emphasize that the following key features of distance learning are flexibility, modularity, ease-of-use, cost-effectiveness, bandwidth, technology, social equality, teacher's new role, they express thoughts $[1,3]$ :

Thus, the basis of the distance learning process is an intensive independent study focused on and controlled by the listener. It can independently read it in its own table for itself, communicate with the technicians via telephone, e-mail, forum, webinar, web conferencing.

The above-mentioned distance learning form provides the most optimal form of education, methodologies and systematization.

\section{References:}

1. Umarova, G. A. (2008). Improving the teaching methods of quantum physics based on computer technologies in general education: Author's abstract. dis. ... Cand. ped. sciences. (p.24). Tashkent: TDPU.
2. Frolov, Y. V. (2011). Preparation and conduct of webinars: A teaching aid for teachers, students and trainees of the advanced training system. (p.30). Moscow: MGPU.

3. Shabanov, A. G. (2004). Modeling the process of distance learning in the system of continuous 


\begin{tabular}{|c|c|c|c|c|c|c|}
\hline \multirow{4}{*}{ Impact Factor: } & ISRA (India) & $=3.117$ & SIS (USA) & $=0.912$ & ICV (Poland) & $=6.630$ \\
\hline & ISI (Dubai, UAE & $=0.829$ & РИНЦ (Russia & $=\mathbf{0 . 1 5 6}$ & PIF (India) & $=1.940$ \\
\hline & GIF (Australia) & $=0.564$ & ESJI (KZ) & $=8.716$ & IBI (India) & $=4.260$ \\
\hline & JIF & $=1.500$ & SJIF (Morocco & $=5.667$ & OAJI (USA) & $=0.350$ \\
\hline
\end{tabular}

education: Dis. ... doc ped. sciences. (p.357). Barnaul: University.

4. Shalaev, I. K. (2000). Motivational Targeted Program Management: Theory, Technology, Practice: A Manual on Psychology of Management. (p.271). Barnaul: publishing house BSPU.

5. Sharifzyanova, K. S. (2014). Designing an individual educational trajectory for improving the qualifications of teachers in an information educational environment. Author. dis. ped.nauk. (p.24). Kazan.

6. Shchennikov, S. A. (2003). Development of an open distance professional education system: Dis. ... doc ped. sciences. (p.456). Moscow.

7. Alsos, G. A., \& Clausen, T. H. (2014). The startup processes of tourism firms: The use of causation and effectuation strategies. Handbook of Research on Innovation in Tourism Industries, (March 2017), 181-202. https://doi.org/10.4337/9781782548416.00016

8. Bobur, S. B., Obidjon, K., Pardaev, O. M., Sergio, R. R., Mukhammadkhon, S. B., \& Bakhodir, N. M. (2015). The role of social media, user generated platforms and crowd sourcing in the development of tourism destinations. Journal of Hospitality Management and Tourism. https://doi.org/10.5897/JHMT2015.0144

9. Carter, N. M., Gartner, W. B., \& Reynolds, P. D. (1996). Exploring start-up event sequences.
Journal of Business Venturing, 11(3), 151-166. https://doi.org/10.1016/0883-9026(95)00129-8

10. Eastman, C. I., \& Burgess, H. J. (2009). How to Travel the World Without Jet Lag. Sleep Medicine Clinics. https://doi.org/10.1016/j.jsmc.2009.02.006

11. Kalpakjian, S., \& Schmid, S. (2014). Manufacturing engineering and technology. Retrieved from https://www.researchgate.net/profile/Vijay_Sek ar2/publication/262156319_Manufacturing_En gineering_and_Technology/links/00b49536c9c 352428b000000.pdf

12. Mukhtarov, F., Fox, S., Mukhamedova, N., \& Wegerich, K. (2015). Interactive institutional design and contextual relevance: Water user groups in Turkey, Azerbaijan and Uzbekistan. Environmental Science and Policy, 53, 206-214. https://doi.org/10.1016/j.envsci.2014.10.006

13. Sobirov, B. (2018). The concept of the tourist economic zone. Case of Uzbekistan. World Scientific News, 98(April), 34-45.

14. Welch, A. R., \& Yang, R. (2011). A Pearl on the Silk Road? In The Internationalization of East Asian Higher Education (pp. 63-89). New York: Palgrave Macmillan US. https://doi.org/10.1057/9781137002006_4 